\title{
SISTEM PAKAR UNTUK MENDIAGNOSIS HAMA DAN PENYAKIT TANAMAN PISANG DENGAN TEOREMA BAYES
}

\author{
Lievia Anjhelina Maharani ${ }^{1}$, Gibtha Fitri Laxmi ${ }^{2}$, Freza Riana ${ }^{3}$ \\ Program Studi Teknik Informatika, Fakultas Teknik \& Sains 1, 2,3 \\ Universitas Ibn Khaldun Bogor \\ Jl. KH. Sholeh Iskandar Km.2 Kota Bogor \\ $\underline{\text { lieviaanjhelinam28@gmail.com }}^{1}$, gibtha.fitri.laxmi@ft.uika-bogor.ac.id ${ }^{2}, \underline{\text { freza } @ \text { ft.uika-bogor.ac.id }}^{3}$
}

\begin{abstract}
Abstrak
Tanaman pisang merupakan salah satu tanaman yang banyak dijumpai pada daerah-daerah di Indonesia, meski begitu di Indonesia sendiri masih minim informasi yang diterima masyarakat tentang hama dan penyakit yang dapat menyerang tanaman pisang dan cara mengatasinya. Terbatasnya ketersediaan seorang pakar di berbagai tempat atau wilayah di Indonesia menyebabkan terlambatnya masyarakat dalam mengatasi hama dan penyakit tanaman pisang, maka dari itu penelitian kali ini membuat sebuah sistem pakar berbasis website untuk mendiagnosis hama dan penyakit tanaman pisang dengan menggunakan 11 data yang terdiri dari 5 hama dan 6 penyakit, serta 48 data gejala yang akan diproses menggunakan metode Teorema Bayes untuk menghasilkan nilai probabilitas suatu hama atau penyakit berdasarkan gejala yang timbul pada tanaman pisang. penelitian ini menghasilkan nilai akurasi sebesar $86,53 \%$. Nilai akurasi diperoleh dari hasil perbandingan antara diagnosis pakar dengan sistem menggunakan Teorema Bayes berdasarkan 52 data yang diujikan. Sistem pakar ini dapat membantu masyarakat dalam mendiagnosis hama dan penyakit tanaman pisang.
\end{abstract}

Kata kunci: Hama, Penyakit, Sistem Pakar, Tanaman Pisang, Teorema Bayes

\begin{abstract}
Banana plants are one of the plants that are often found in areas in Indonesia, even though in Indonesia itself there is still minimal information received by the public about pests and diseases that can attack banana plants and how to overcome them. The limited availability of an expert in various places or regions in Indonesia causes the community to be late in dealing with pests and diseases of banana plants,
\end{abstract}

therefore this research creates a website-based expert system to diagnose pests and diseases of banana plants using 11 data consisting of 5 pests and 6 diseases, as well as 48 symptom data that will be processed using the Bayes Theorem method to produce a probability value of a pest or disease based on the symptoms that arise in banana plants. This study resulted in an accuracy value of $86.53 \%$. The accuracy value is obtained from the comparison between expert diagnosis and the system using the Bayes theorem based on 52 tested data. This expert system can help the community in diagnosing banana plant pests and diseases.

Keywords: Banana Plant, Bayes Theorem, Disease, Expert System, Pest

\section{Pendahuluan}

Tanaman pisang banyak dijumpai pada daerahdaerah di Indonesia, menurut Badan Pusat Statistik (BPS) dan Direktorat Jenderal Hortikultura Negara Indonesia menjadi salah satu negara penghasil pisang terbesar di dunia pada tahun 2015, pada tahun 2016 Indonesia memproduksi pisang sebanyak 7 juta ton, di tahun 2017 sebanyak 7,162 juta ton, ditahun 2018 sebanyak 7,264 juta ton dan 2019 sebayak 7,280 juta ton. Terdapat tiga provinsi di Indonesia dengan produksi pisang terbanyak, diantaranya provinsi Jawa Timur sebanyak 2.116.974 ton, diikuti provinsi Jawa Barat sebanyak 1.220.174 ton dan provinsi Lampung sebanyak 1.209.545 ton.

Produksi pisang di Indonesia setiap tahunnya mengalami peningkatan, tetapi di Indonesia sendiri masih minim informasi yang diterima masyarakat tentang hama dan penyakit yang dapat menyerang tanaman pisang (Riana \& Primasari, 2019). Terbatasnya ketersediaan seorang pakar di berbagai tempat atau wilayah di Indonesia menyebabkan 
minimnya informasi dan terlambatnya masyarakat dalam mengatasi hama dan penyakit sehingga tanaman pisang tidak tumbuh dengan baik. Mengatasi permasalahan tersebut perlu adanya sebuah sistem pakar. Menurut Martin \& Oxman sistem pakar adalah sebuah sistem yang dirancang berbasis komputer dengan menggunakan pengetahuan, fakta, dan teknik penalaran dalam memecahkan suatu masalah yang pada umumnya hanya dapat dipecahkan oleh seorang pakar di dalam bidang atau ilmu tertentu (Kusrini, 2006). Sistem pakar dapat membantu masyarakat khususnya para petani tanaman pisang dalam mendiagnosis hama atau penyakit dilihat melalui gejala yang timbul, ketika tidak dapat bertemu dengan pakar tanaman pisang. Pada penelitian sistem pakar ini menggunakan metode Teorema Bayes.

Teorema Bayes adalah metode yang digunakan untuk menghitung nilai probabilitas atau kemungkinan suatu penyakit yang dapat dilihat melalui gejala-gejala yang timbul. Terdapat penelitian yang juga menggunakan metode Teorema Bayes, salah satunya sistem pakar untuk mengidentifikasi tumbuhan padi yang menghasilkan nilai akurasi sebesar 90\% (Siregar, 2015). Beberapa penelitian yang menggunakan metode Teorema Bayes menunjukan tingkat akurasi yang cukup baik dalam mendiagnosis suatu penyakit, maka dari itu pada penelitian tentang sistem pakar kali ini menggunakan metode Teorema Bayes untuk mendiagnosis hama dan penyakit tanaman pisang.

\section{TinjauAn Pustaka}

\section{Tanaman Pisang}

Tanaman pisang merupakan tanaman yang berasal dari kawasan Asia Tenggara, termasuk Indonesia. Banyaknya manfaat yang terdapat pada tanaman pisang membuat tanaman ini menjadi salah satu tanaman serbaguna yang dapat dimanfaatkan, bahkan sebagian masyarakat Indonesia menjadikan tanaman pisang sebagai ladang penghasilan (Suhartanto, Sobir, \& Heri, 2012). Buah Pisang merupakan buah yang mempunyai gizi yang sangat tinggi, mengandung vitamin, mineral serta karbohidrat (Riana \& Primasari, 2019).

\section{Sistem Pakar}

Menurut Wijaya (2007) Sistem pakar adalah sebuah program komputer yang dirancang untuk mengambil keputusan seperti keputusan seorang pakar, dimana sistem pakar menggunakan pengetahuan (Knowledge), fakta dan teknik berfikir dalam menyelesaikan masalah yang biasanya hanya dapat diselesaikan oleh seorang pakar di bidang yang tertentu (Hayadi, 2018).

\section{Teorema Bayes}

Teorema Bayes adalah metode yang ditemukan oleh pendeta bernama Thomas Bayes pada tahun 1763 dan disempurnakan oleh Laplace. Menurut Hadini (2017) Metode Teorema Bayes menerapkan aturan yang dihubungkan dengan nilai probabilitas atau kemungkinan untuk menghasilkan suatu keputusan dan informasi yang tepat berdasarkan penyebab yang terjadi (Ramadhan \& S.Pane, 2018). Secara umum rumus Teorema Bayes dapat dilihat pada Rumus 1.

$$
=\frac{P\left(H_{i} \mid E\right)}{\sum_{k=1}^{n} P\left(E \mid H_{i}\right) * P\left(H_{i}\right)}
$$

Keterangan:

$\begin{array}{ll}P\left(H_{i} \mid E\right) & \begin{array}{l}\text { : Probabilitas hipotesis Hi terjadi, jika } \\ \text { evidence } \mathrm{E} \text { terjadi }\end{array} \\ P\left(E \mid H_{i}\right) & \begin{array}{l}\text { : Probabilitas munculnya } \text { evidence } \mathrm{E}, \mathrm{jika} \\ \text { hipotesis Hi terjadi }\end{array} \\ P\left(H_{i}\right) \quad \begin{array}{l}\text { : Probabilitas hipotesis Hi tanpa } \\ \text { memancang } \text { evidence } \text { apapun }\end{array} \\ \mathrm{n} & \text { : Jumlah hipotesis yang terjadi }\end{array}$

\section{Analisis dan Perancangan}

\section{Analisis}

Pada tahap ini dilakukan analisis kebutuhan sistem yang meliputi analisis proses bisnis baru, basis pengetahuan, dan penerapan metode Teorema Bayes.

\section{Analisis Proses Bisnis Baru}

Analisis proses bisnis baru adalah sebuah gambaran tentang sistem yang akan dibangun. Proses bisnis baru yang diusulkan yaitu sebuah sistem pakar, dimana user dapat mendiagnosis hama atau penyakit tanaman pisang menggunakan sistem berbasis website dengan memilih gejala yang sesuai atau yang timbul pada tanaman pisang. Analisis proses bisnis baru dapat dilihat pada Gambar 1.

Lievia Anjhelina Maharani, Gibtha Fitri Laxmi, Freza Riana 


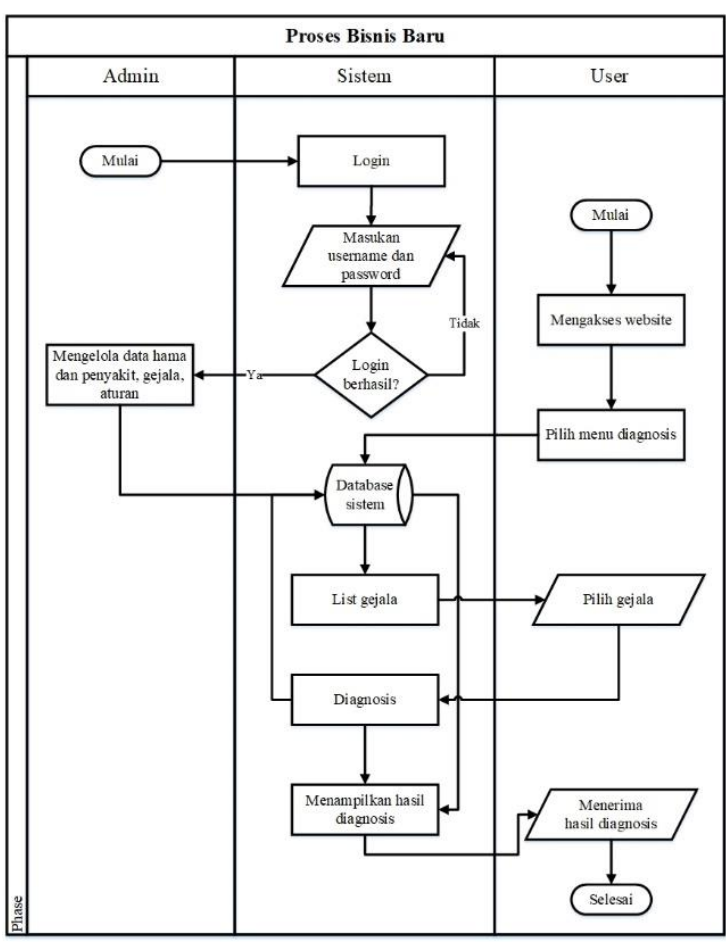

Gambar 1 Proses Bisnis Baru

\section{Basis Pengetahuan}

Basis Pengetahuan adalah salah satu komponen dari sistem pakar yang terdiri dari fakta dan aturan, yaitu data atau informasi yang telah diperoleh dari pakar ataupun studi literatur. Pada penelitian ini data yang dikumpulkan berjenis data sekunder yang diperoleh dari ibu Freza Riana, S.Si., M.Si yang langsung didapat dari Dr. Catur Hermanto selaku pakar penyakit tanaman pisang Balai Pengkajian Teknologi Pertanian Jawa Timur. Data-data yang diperoleh dapat dilihat pada Tabel 1.

Tabel 1 Data Hama, Penyakit dan Gejala

\begin{tabular}{|c|c|c|c|}
\hline KP & Nama Penyakit & KG & Nama Gejala \\
\hline \multirow{6}{*}{ P01 } & \multirow{6}{*}{$\begin{array}{c}\text { Bercak Daun Sigatoka } \\
\text { (Penyebab:Cendawan } \\
\text { Mycosphaerella sp) }\end{array}$} & G01 & $\begin{array}{l}\text { Garis-garis coklat kehitaman paralel } \\
\text { pada helaian daun }\end{array}$ \\
\hline & & G02 & $\begin{array}{l}\text { Bercak memanjang berukuran } 2 \times \\
20 \mathrm{~mm} \text { paralel pada helaian daun }\end{array}$ \\
\hline & & G03 & $\begin{array}{l}\text { Pada awal perkembangan, bercak } \\
\text { tersusun segaris searah dengan ibu } \\
\text { tulang daun (midrib) }\end{array}$ \\
\hline & & G04 & $\begin{array}{l}\text { Bercak daun membesar berbentuk } \\
\text { oval atau memanjang. Terdapat } \\
\text { lingkaran berwarna kuning pada } \\
\text { pinggiran bercak }\end{array}$ \\
\hline & & G05 & $\begin{array}{l}\text { Bercak bergabung sehingga daun } \\
\text { mengalami nekrosis dan mengering } \\
\text { pada sebagian atau seluruh helaian } \\
\text { daun }\end{array}$ \\
\hline & & G06 & berkembang \\
\hline
\end{tabular}

Bercak Daun Cordana Cordana musae)

P03 Bersilang (Penyebab: Cendawan Phyllachora musicola)

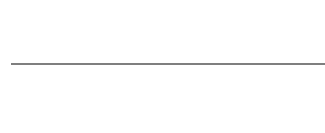

Penyakit Layu Fusarium (Penyebab: P04 Cendawan Fusarium oxysporum f.sp cubense)
P02 (Penyebab: Cendawan

G07

G08

G0 daun yang tua

mengalami pematangan lebih cepat Bercak berwarna kuning sampai ketupat atau berbentuk seperti mata

Bercak dengan pusat lingkaran nekrosis berwarna abu-abu Bercak terjadi di pinggiran daun dan berkembang menuju ke ibu tulang

Bercak bergabung sehingga

G10 menyebabkan daun menguning dan mengering

G11 Bercak berwarna hitam dengan 4 sudut sehingga berbentuk silang

G12 Bercak memanjang searah dengan

tulang daun (vein)

G13 Bercak menyebar secara acak

G14 Bercak bersilang berukuran sampai dengan $6 \mathrm{~cm}$ panjang

Bercak bergabung menyebabkan

G15 daun mengering, tetapi helaian daun tidak patah

G16 Daun menguning dimulai dari tepi daun dan dari daun-daun yang tua

Helaian daun mengering dan

G17 menggantung karena pangkal tangkai daunnya patah

G18 Batang semu terbelah atau pecah

Terjadi perubahan warna jaringan pembuluh menjadi coklat pada

batang semu: berupa titik-titik

G19 coklat apabila batang semu dipotong melintang atau garis coklat memanjang apabila batang semu dipotong membujur

Terdapat necrosis pada bonggol. Apabila bonggol dibelah melintang,

G20 terdapat nekrosis berwarna coklat sampai hitam melingkari bonggol Bunga (jantung) membusuk dan

G21 mengering

22 Daging buah busuk berlendir berwarna merah

G23 Buah membusuk dan mengering

Daun menguning pada seluruh

G24 helaian daun, terutama dimulai dari

Penyakit Darah

P05 (Penyebab: Bakteri

Ralstonia sp) daun termuda

Pada empulur dan tangkai tandan terdapat perubahan warna menjadi

G25 coklat-kemerahan. Pemotongan melintang pada tangkai tandan akan memperlihatkan titik-titik berwarna coklat kemerahan

G26 Bonggol busuk dan berbau tidak sedap

G27 Daun mengecil dan berdiri tegak

G28 Daun pucat

Penyakit Kerdil Pisang P06 (Penyebab: Bunchy

G29 Ruas daun

$$
\text { top virus) }
$$

G30 terdapat bercak atau garis-garis berwarna hijau gelap

G31 Tanaman kerdil

G32 Tanaman tumbuh merana

G33 Pertumbuhan buah tidak normal

G34 Tanaman rebah

Serangan Nematoda

P07 (Penyebab: Nematode Perakaran tidak tumbuh normal,

G35 akar serabut tidak tumbuh, ujung akar membusuk

Nekrosis pada akar. Pemotongan

G36 membujur akan menunjukkan garis memanjang berwarna hitam

Lievia Anjhelina Maharani, Gibtha Fitri Laxmi, Freza Riana 


\begin{tabular}{|c|c|c|c|}
\hline & & & sepanjang perakaran \\
\hline \multirow{5}{*}{ P08 } & \multirow{5}{*}{$\begin{array}{l}\text { Hama Penggerek } \\
\text { Bonggol Pisang } \\
\text { (Penyebab: Kumbang } \\
\text { Cosmopolitus } \\
\text { sordidus) }\end{array}$} & G32 & Tanaman tumbuh merana \\
\hline & & G33 & Pertumbuhan buah tidak normal \\
\hline & & G35 & $\begin{array}{l}\text { Perakaran tidak tumbuh normal, } \\
\text { akar serabut tidak tumbuh, ujung } \\
\text { akar membusuk }\end{array}$ \\
\hline & & G37 & $\begin{array}{l}\text { Terdapat lubang seperti terowongan } \\
\text { pada bonggol. Hal ini mudah dilihat } \\
\text { apabila bonggol dipotong melintang }\end{array}$ \\
\hline & & G38 & $\begin{array}{l}\text { Terdapat larva serangga berwarna } \\
\text { putih kekuningan atau kumbang } \\
\text { dewasa berwarna coklat kehitaman } \\
\text { berukuran } 0.6 \mathrm{~cm} \text { pada lubang } \\
\text { terowongan di bonggol }\end{array}$ \\
\hline \multirow{5}{*}{ P09 } & \multirow{5}{*}{$\begin{array}{c}\text { Hama Penggerek } \\
\text { Batang Pisang } \\
\text { (Penyebab: Kumbang } \\
\text { Odoiporus longicollis) }\end{array}$} & G32 & Tanaman tumbuh merana \\
\hline & & G33 & Pertumbuhan buah tidak normal \\
\hline & & G39 & $\begin{array}{l}\text { Beberapa helaian daun mengering, } \\
\text { biasanya dari daun termuda karena } \\
\text { pelepahnya dimakan serangga }\end{array}$ \\
\hline & & G40 & $\begin{array}{l}\text { Batang semu berlubang-lubang dan } \\
\text { mengeluarkan lendir berwarna } \\
\text { bening }\end{array}$ \\
\hline & & G41 & $\begin{array}{l}\text { Terdapat larva serangga berwarna } \\
\text { putih kekuningan atau kumbang } \\
\text { dewasa berwarna hitam mengkilat } \\
\text { berukuran } 0.6 \mathrm{~cm} \text { pada lubang di } \\
\text { batang semu }\end{array}$ \\
\hline \multirow{3}{*}{ P10 } & \multirow{3}{*}{$\begin{array}{l}\text { Hama Penggulung } \\
\text { Daun Pisang } \\
\text { (Penyebab: Ulat } \\
\text { Erionata thrax) }\end{array}$} & G42 & $\begin{array}{l}\begin{array}{l}\text { Lembaran daun } \\
\text { menggulung }\end{array} \\
\end{array}$ \\
\hline & & G43 & Gulungan daun mengering \\
\hline & & G44 & $\begin{array}{l}\text { Terdapat ulat berwarna putih } \\
\text { kehijauan berbedak di dalam } \\
\text { gulungan daun }\end{array}$ \\
\hline \multirow{4}{*}{ P11 } & \multirow{4}{*}{$\begin{array}{l}\text { Hama Kudis Buah } \\
\text { (Penyebab: Ulat } \\
\text { Nacoleia octasema) }\end{array}$} & G45 & $\begin{array}{l}\text { Kulit buah berkudis atau burik, } \\
\text { terutama pada buah pada sisir paling } \\
\text { bawah atau paling muda }\end{array}$ \\
\hline & & G46 & $\begin{array}{l}\text { Terdapat kotoran pada sela-sela jari } \\
\text { buah pada sisir buah yang terserang }\end{array}$ \\
\hline & & G47 & $\begin{array}{l}\text { Terdapat ulat berwarna coklat gelap } \\
\text { di sela-sela jari buah }\end{array}$ \\
\hline & & G48 & $\begin{array}{l}\text { Terdapat ulat berwarna abu-abu } \\
\text { orange di sela-sela seludang bunga }\end{array}$ \\
\hline
\end{tabular}

3. Penerapan Metode Teorema Bayes

Penerapan metode Teorema Bayes merupakan perhitungan secara manual yang menjelaskan tentang tahapan-tahapan dalam menghitung nilai probabilitas suatu hama atau penyakit berdasarkan gejala yang dipilih. Berikut contoh perhitungan dari beberapa gejala yang dipilih: Garis-garis coklat kehitaman paralel pada helaian daun (G01), Bercak awal perkembangan, bercak tersusun segaris searah dengan ibu tulang daun (midrib) (G02), dan Bercak daun membesar berbentuk oval atau memanjang. Terdapat lingkaran berwarna kuning pada pinggiran bercak (G04). Berdasarkan gejala yang dipilih maka perhitungannya sebagai berikut:

1. Mendefinisikan bobot setiap gejala yang dipilih:

$$
\begin{aligned}
& \mathrm{G} 01=0,9\left(\mathrm{E} \mid \mathrm{H}_{1}\right), \mathrm{G} 02=0,85\left(\mathrm{E} \mid \mathrm{H}_{2}\right), \\
& \mathrm{G} 04=0,7\left(\mathrm{E} \mid \mathrm{H}_{4}\right)
\end{aligned}
$$

2. Menjumlahkan bobot setiap gejala yang dipilih:

$$
\begin{aligned}
\sum_{\mathrm{k}=1}^{3} & =\mathrm{G} 01+\mathrm{G} 02+\mathrm{G} 04 \\
& =0,9+0,85+0,7 \\
& =2,45
\end{aligned}
$$

3. Setelah hasil penjumlahan diketahui, maka selanjutnya menghitung nilai semesta:

$$
\begin{aligned}
& \mathrm{P}\left(\mathrm{H}_{1}\right)=\frac{\mathrm{P}\left(\mathrm{H}_{1}\right)}{\sum_{\mathrm{k}=1}^{3}}=\frac{0,9}{2,45}=0,3673 \\
& \mathrm{P}\left(\mathrm{H}_{2}\right)=\frac{\mathrm{P}\left(\mathrm{H}_{2}\right)}{\sum_{\mathrm{k}=1}^{3}}=\frac{0,85}{2,45}=0,3469 \\
& \mathrm{P}\left(\mathrm{H}_{4}\right)=\frac{\mathrm{P}\left(\mathrm{H}_{4}\right)}{\sum_{\mathrm{k}=1}^{3}}=\frac{0,7}{2,45}=0,2857
\end{aligned}
$$

4. Setelah nilai $\mathrm{P}$ (Hi) diketahui, probabilitas hipotesis Hi tanpa memandang evidence apapun, maka langkah selanjutnya adalah:

$$
\begin{aligned}
& \mathrm{P}\left(\mathrm{H}_{1}\right) * \mathrm{P}\left(\mathrm{E} \mid \mathrm{H}_{1}\right)+\mathrm{P}\left(\mathrm{H}_{2}\right) * \mathrm{P}\left(\mathrm{E} \mid \mathrm{H}_{2}\right)+\mathrm{P}\left(\mathrm{H}_{4}\right) \\
& * \mathrm{P}\left(\mathrm{E} \mid \mathrm{H}_{4}\right) \\
& =(0,3673 * 0,9)+(0,3469 * 0,85)+ \\
& (0,2857 * 0,7) \\
& =0,3306+0,2949+0,2 \\
& =0,8255
\end{aligned}
$$

5. Menghitung nilai $\mathrm{P}(\mathrm{Hi} \mid \mathrm{E})$ atau probabilitas hipotesis Hi terjadi, jika evidence E terjadi:

$$
\begin{aligned}
& P\left(H_{1} \mid E\right)=\frac{0,9 * 0,3673}{0,8255}=0,4005 \\
& P\left(H_{2} \mid E\right)=\frac{0,85 * 0,3469}{0,8255}=0,3572 \\
& P\left(H_{4} \mid E\right)=\frac{0,7 * 0,2857}{0,8255}=0,2423
\end{aligned}
$$

6. Menghitung total Bayes

$$
\begin{aligned}
& \sum_{k=1}^{3} \text { Bayes }=\text { Bayes } 1+\text { Bayes } 2+\text { Bayes } 3 \\
& =(0,9 * 0,4005)+(0,85 * 0,3572)+(0,7 * \\
& 0,2423) \\
& =0,3604+0,3036+0,1696
\end{aligned}
$$




$$
\begin{aligned}
& =0,8337 * 100 \\
& =83,37 \%
\end{aligned}
$$

Hasil dari perhitungan menggunakan metode Teorema Bayes diatas dapat disimpulkan bahwa tanaman pisang terserang penyakit Bercak Daun Sigatoka dengan nilai probabilitas $83,37 \%$.

\section{Perancangan Sistem}

Perancangan sistem dilakukan untuk memberikan gambaran atau model sistem yang akan dibangun. Pada penelitian ini perancangan sistem terdiri dari Use case Diagram yang dapat dilihat pada Gambar 2, Activity Diagram, dan Sequence Diagram.

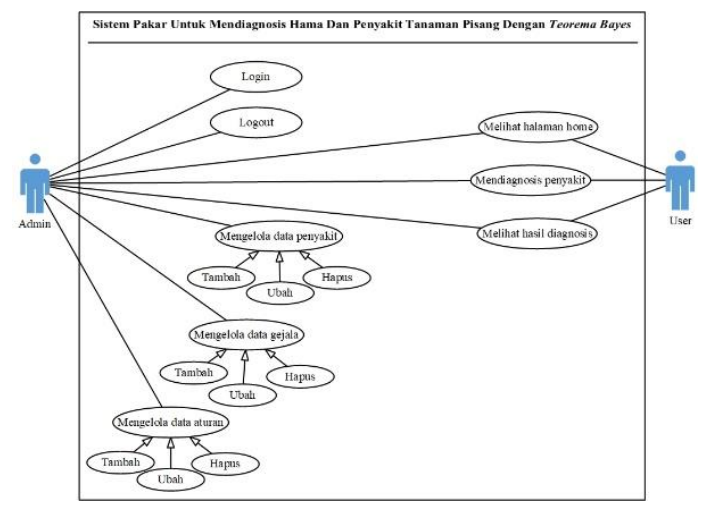

Gambar 2 Use Case Diagram

\section{Hasil Dan Pembahasan}

\section{Implementasi Sistem}

Implementasi sistem pada penelitian ini adalah penerapan perancangan sistem kedalam bahasa pemrograman PHP dan MySql sebagai database. Berikut tampilan halaman user pada website sistem pakar ini.

1. Tampilan halaman home dapat dilihat pada Gambar 3.

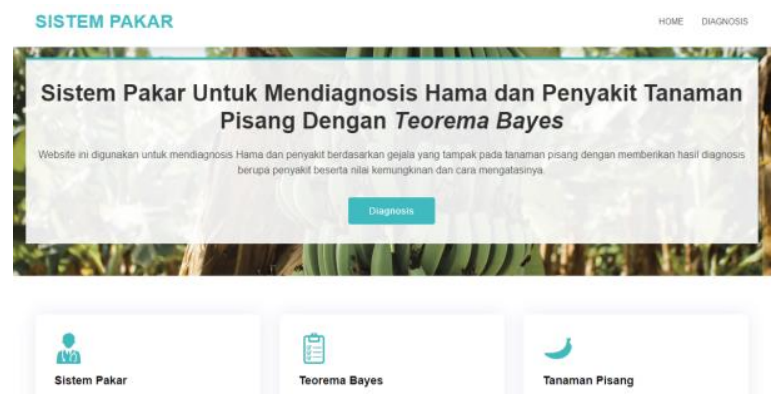

Gambar 3 Halaman Home

2. Tampilan halaman diagnosis dapat dilihat pada Gambar 4.

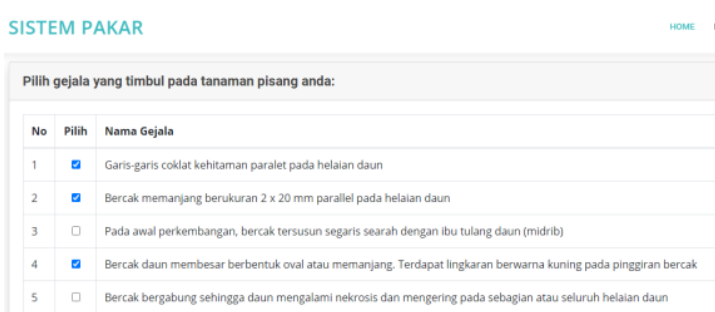

Gambar 4 Halaman Diagnosis

3. Tampilan halaman hasil diagnosis dapat dilihat pada Gambar 5.

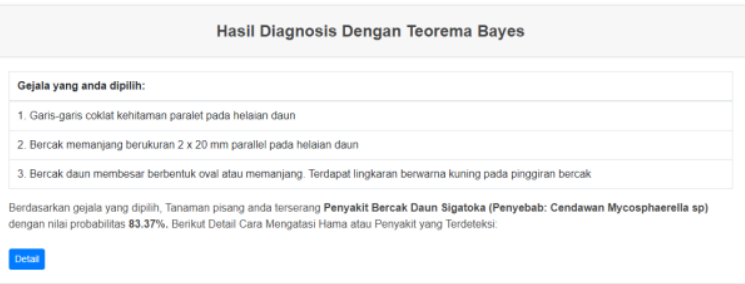

Gambar 5 Halaman Hasil Diagnosis

\section{Pengujian Sistem}

Pada penelitian ini dilakukan pengujian sistem dengan mengunakan metode blackbox yang bertujuan untuk mengetahui fungsi yang terdapat pada sistem dan memastikan fungsi tersebut sudah dapat berjalan dengan baik.

\section{Evaluasi Sistem}

Evaluasi sistem menjelaskan tentang hasil perbandingan antara diagnosis pakar dengan sistem berdasarkan 52 data yang diujikan. Evaluasi Sistem dapat dilihat pada Tabel 2.

\begin{tabular}{|c|c|c|c|c|}
\hline \multirow{2}{*}{ No } & \multirow{2}{*}{ Gejala } & \multicolumn{2}{|c|}{ Hasil Diagnosis } & \multirow{2}{*}{$\begin{array}{c}\text { Keteran } \\
\text { gan }\end{array}$} \\
\hline & & Pakar & Sistem & \\
\hline 1 & $\begin{array}{l}\text { G01, G16, } \\
\text { G19 }\end{array}$ & Layu Fusarium & Layu Fusarium & Sesuai \\
\hline 2 & $\begin{array}{l}\text { G04, G09, } \\
\text { G10 }\end{array}$ & $\begin{array}{l}\text { Bercak Daun } \\
\text { Sigatoka }\end{array}$ & $\begin{array}{l}\text { Bercak Daun } \\
\text { Sigatoka }\end{array}$ & Sesuai \\
\hline 3 & $\begin{array}{l}\text { G10, G11, } \\
\text { G14 }\end{array}$ & Bercak Bersilang & Bercak Bersilang & Sesuai \\
\hline 4 & $\begin{array}{l}\text { G01, G02, } \\
\text { G03, G13 }\end{array}$ & $\begin{array}{l}\text { Bercak Daun } \\
\text { Sigatoka }\end{array}$ & $\begin{array}{l}\text { Bercak Daun } \\
\text { Sigatoka }\end{array}$ & Sesuai \\
\hline 5 & G06, G09 & $\begin{array}{l}\text { Bercak Daun } \\
\text { Sigatoka }\end{array}$ & $\begin{array}{l}\text { Bercak Daun } \\
\text { Cordana }\end{array}$ & $\begin{array}{l}\text { Tidak } \\
\text { Sesuai }\end{array}$ \\
\hline 6 & $\mathrm{G} 15, \mathrm{G} 16$ & Layu Fusarium & Layu Fusarium & Sesuai \\
\hline 7 & $\begin{array}{l}\text { G06, G16, } \\
\text { G17 }\end{array}$ & Layu Fusarium & Layu Fusarium & Sesuai \\
\hline
\end{tabular}

Tabel 2 Evaluasi Sistem

Lievia Anjhelina Maharani, Gibtha Fitri Laxmi, Freza Riana 


\begin{tabular}{|c|c|c|c|c|}
\hline 8 & $\begin{array}{l}\text { G09, G10, } \\
\text { G18 }\end{array}$ & Layu Fusarium & Layu Fusarium & Sesuai \\
\hline 9 & $\begin{array}{l}\text { G07, G08, } \\
\text { G15 }\end{array}$ & $\begin{array}{l}\text { Bercak Daun } \\
\text { Cordana }\end{array}$ & $\begin{array}{l}\text { Bercak Daun } \\
\text { Cordana }\end{array}$ & Sesuai \\
\hline 10 & $\begin{array}{l}\text { G17, G18, } \\
\text { G19 }\end{array}$ & Layu Fusarium & Layu Fusarium & Sesuai \\
\hline 11 & $\mathrm{G} 13, \mathrm{G} 14$ & Bercak Bersilang & $\begin{array}{l}\text { Bercak } \\
\text { Bersilang }\end{array}$ & Sesuai \\
\hline 12 & $\begin{array}{l}\text { G04, G05, } \\
\text { G06, G10 }\end{array}$ & $\begin{array}{l}\text { Bercak Daun } \\
\text { Sigatoka }\end{array}$ & $\begin{array}{l}\text { Bercak Daun } \\
\text { Sigatoka }\end{array}$ & Sesuai \\
\hline 13 & G15, G16 & Layu Fusarium & Layu Fusarium & Sesuai \\
\hline 14 & $\begin{array}{l}\text { G18, G19, } \\
\text { G20 }\end{array}$ & Layu Fusarium & Layu Fusarium & Sesuai \\
\hline 15 & $\begin{array}{l}\text { G11, G12, } \\
\text { G13 }\end{array}$ & Bercak Bersilang & $\begin{array}{l}\text { Bercak } \\
\text { Bersilang }\end{array}$ & Sesuai \\
\hline 16 & $\begin{array}{l}\text { G01, G02, } \\
\text { G07 }\end{array}$ & $\begin{array}{l}\text { Bercak Daun } \\
\text { Cordana }\end{array}$ & $\begin{array}{l}\text { Bercak Daun } \\
\text { Cordana }\end{array}$ & Sesuai \\
\hline 17 & $\begin{array}{l}\text { G11, G12, } \\
\text { G13, G19 }\end{array}$ & Layu Fusarium & Layu Fusarium & Sesuai \\
\hline 18 & G03, G04 & $\begin{array}{l}\text { Bercak Daun } \\
\text { Sigatoka }\end{array}$ & $\begin{array}{l}\text { Bercak Daun } \\
\text { Sigatoka }\end{array}$ & Sesuai \\
\hline 19 & G16, G17 & Layu Fusarium & Layu Fusarium & Sesuai \\
\hline 20 & $\begin{array}{l}\text { G02, G03, } \\
\text { G04, G05 }\end{array}$ & $\begin{array}{l}\text { Bercak Daun } \\
\text { Sigatoka }\end{array}$ & $\begin{array}{l}\text { Bercak Daun } \\
\text { Sigatoka }\end{array}$ & Sesuai \\
\hline 21 & G14, G15 & Bercak Bersilang & $\begin{array}{l}\text { Bercak } \\
\text { Bersilang }\end{array}$ & Sesuai \\
\hline 22 & G05, G06 & $\begin{array}{l}\text { Bercak Daun } \\
\text { Sigatoka }\end{array}$ & $\begin{array}{l}\text { Bercak Daun } \\
\text { Sigatoka }\end{array}$ & Sesuai \\
\hline 23 & $\begin{array}{l}\text { G08, G09, } \\
\text { G10 }\end{array}$ & $\begin{array}{l}\text { Bercak Daun } \\
\text { Sigatoka }\end{array}$ & $\begin{array}{l}\text { Bercak Daun } \\
\text { Cordana }\end{array}$ & $\begin{array}{l}\text { Tidak } \\
\text { Sesuai }\end{array}$ \\
\hline 24 & $\begin{array}{l}\text { G01, G02, } \\
\text { G03, G04, } \\
\text { G05 }\end{array}$ & $\begin{array}{l}\text { Bercak Daun } \\
\text { Sigatoka }\end{array}$ & $\begin{array}{l}\text { Bercak Daun } \\
\text { Sigatoka }\end{array}$ & Sesuai \\
\hline 25 & $\begin{array}{l}\text { G11, G12, } \\
\text { G13 }\end{array}$ & Bercak Bersilang & $\begin{array}{l}\text { Bercak } \\
\text { Bersilang }\end{array}$ & Sesuai \\
\hline 26 & G09, G10 & $\begin{array}{l}\text { Bercak Daun } \\
\text { Sigatoka }\end{array}$ & $\begin{array}{l}\text { Bercak Daun } \\
\text { Cordana }\end{array}$ & $\begin{array}{l}\text { Tidak } \\
\text { Sesuai }\end{array}$ \\
\hline 27 & $\begin{array}{l}\text { G07, G08, } \\
\text { G09 }\end{array}$ & $\begin{array}{l}\text { Bercak Daun } \\
\text { Cordana }\end{array}$ & $\begin{array}{l}\text { Bercak Daun } \\
\text { Cordana }\end{array}$ & Sesuai \\
\hline 28 & G16, G17 & Layu Fusarium & Layu Fusarium & Sesuai \\
\hline 29 & $\begin{array}{l}\text { G15, G19, } \\
\text { G20 }\end{array}$ & Layu Fusarium & Layu Fusarium & Sesuai \\
\hline 30 & $\begin{array}{l}\text { G09, G10, } \\
\text { G16 }\end{array}$ & Layu Fusarium & Layu Fusarium & Sesuai \\
\hline 31 & $\begin{array}{l}\text { G06, G10, } \\
\text { G16 }\end{array}$ & Layu Fusarium & Layu Fusarium & Sesuai \\
\hline 32 & G13, G19 & Layu Fusarium & Layu Fusarium & Sesuai \\
\hline 33 & $\begin{array}{l}\text { G33, G35, } \\
\text { G37 }\end{array}$ & $\begin{array}{l}\text { Penggerek } \\
\text { Bonggol Pisang }\end{array}$ & $\begin{array}{l}\text { Penggerek } \\
\text { Bonggol Pisang }\end{array}$ & Sesuai \\
\hline 34 & $\begin{array}{l}\text { G33, G35, } \\
\text { G39 }\end{array}$ & $\begin{array}{l}\text { Serangan } \\
\text { Nematoda }\end{array}$ & $\begin{array}{l}\text { Serangan } \\
\text { Nematoda }\end{array}$ & Sesuai \\
\hline 35 & $\mathrm{G} 32, \mathrm{G} 44$ & $\begin{array}{l}\text { Hama Penggulung } \\
\text { Daun Pisang }\end{array}$ & $\begin{array}{l}\text { Hama } \\
\text { Penggulung } \\
\text { Daun Pisang }\end{array}$ & Sesuai \\
\hline 36 & $\begin{array}{l}\text { G35, G46, } \\
\text { G48 }\end{array}$ & Hama Kudis Buah & $\begin{array}{l}\text { Hama Kudis } \\
\text { Buah }\end{array}$ & Sesuai \\
\hline 37 & $\begin{array}{l}\text { G33, G35, } \\
\text { G37, G39 }\end{array}$ & $\begin{array}{l}\text { Penggerek } \\
\text { Bonggol Pisang }\end{array}$ & $\begin{array}{l}\text { Penggerek } \\
\text { Bonggol Pisang }\end{array}$ & Sesuai \\
\hline 38 & G32, G35 & $\begin{array}{l}\text { Serangan } \\
\text { Nematoda }\end{array}$ & $\begin{array}{l}\text { Serangan } \\
\text { Nematoda }\end{array}$ & Sesuai \\
\hline 39 & $\mathrm{G} 32, \mathrm{G} 46$ & Hama Kudis Buah & $\begin{array}{l}\text { Hama Kudis } \\
\text { Buah }\end{array}$ & Sesuai \\
\hline 40 & $\begin{array}{l}\text { G33, G39, } \\
\text { G44 }\end{array}$ & $\begin{array}{l}\text { Hama Penggulung } \\
\text { Daun Pisang }\end{array}$ & $\begin{array}{l}\text { Hama } \\
\text { Penggulung } \\
\text { Daun Pisang }\end{array}$ & Sesuai \\
\hline 41 & $\mathrm{G} 39, \mathrm{G} 45$ & Hama Kudis Buah & $\begin{array}{l}\text { Hama Kudis } \\
\text { Buah }\end{array}$ & Sesuai \\
\hline 42 & $\begin{array}{l}\text { G43, G44, } \\
\text { G46 }\end{array}$ & $\begin{array}{l}\text { Hama Penggulung } \\
\text { Daun Pisang }\end{array}$ & $\begin{array}{l}\text { Hama } \\
\text { Penggulung } \\
\text { Daun Pisang }\end{array}$ & Sesuai \\
\hline
\end{tabular}

\begin{tabular}{|c|c|c|c|c|}
\hline 43 & $\begin{array}{l}\text { G32, G35, } \\
\text { G45 }\end{array}$ & Hama Kudis Buah & $\begin{array}{l}\text { Hama Kudis } \\
\text { Buah }\end{array}$ & Sesuai \\
\hline 44 & $\begin{array}{l}\text { G33, G39, } \\
\text { G47 }\end{array}$ & Hama Kudis Buah & $\begin{array}{l}\text { Hama Kudis } \\
\text { Buah }\end{array}$ & Sesuai \\
\hline 45 & $\mathrm{G} 42, \mathrm{G} 48$ & Hama Kudis Buah & $\begin{array}{l}\text { Hama } \\
\text { Penggulung } \\
\text { Daun Pisang }\end{array}$ & $\begin{array}{l}\text { Tidak } \\
\text { Sesuai }\end{array}$ \\
\hline 46 & $\mathrm{G} 39, \mathrm{G} 40$ & $\begin{array}{l}\text { Penggerek Batang } \\
\text { Pisang }\end{array}$ & $\begin{array}{l}\text { Penggerek } \\
\text { Batang Pisang }\end{array}$ & Sesuai \\
\hline 47 & $\begin{array}{l}\text { G32, G38, } \\
\text { G43, G44 }\end{array}$ & $\begin{array}{l}\text { Penggerek } \\
\text { Bonggol Pisang }\end{array}$ & $\begin{array}{l}\text { Hama } \\
\text { Penggulung } \\
\text { Daun Pisang }\end{array}$ & $\begin{array}{l}\text { Tidak } \\
\text { Sesuai }\end{array}$ \\
\hline 48 & $\begin{array}{l}\text { G32, G34, } \\
\text { G42 }\end{array}$ & $\begin{array}{l}\text { Serangan } \\
\text { Nematoda }\end{array}$ & $\begin{array}{l}\text { Hama } \\
\text { Penggulung } \\
\text { Daun Pisang }\end{array}$ & $\begin{array}{l}\text { Tidak } \\
\text { Sesuai }\end{array}$ \\
\hline 49 & $\mathrm{G} 34, \mathrm{G} 39$ & $\begin{array}{l}\text { Serangan } \\
\text { Nematoda }\end{array}$ & $\begin{array}{l}\text { Serangan } \\
\text { Nematoda }\end{array}$ & Sesuai \\
\hline 50 & G35 & $\begin{array}{l}\text { Serangan } \\
\text { Nematoda }\end{array}$ & $\begin{array}{l}\text { Serangan } \\
\text { Nematoda }\end{array}$ & Sesuai \\
\hline 51 & $\mathrm{G} 38, \mathrm{G} 40$ & $\begin{array}{l}\text { Penggerek Batang } \\
\text { Pisang }\end{array}$ & $\begin{array}{l}\text { Penggerek } \\
\text { Bonggol Pisang }\end{array}$ & $\begin{array}{l}\text { Tidak } \\
\text { Sesuai }\end{array}$ \\
\hline 52 & $\mathrm{G} 32, \mathrm{G} 47$ & Hama Kudis Buah & $\begin{array}{l}\text { Hama Kudis } \\
\text { Buah }\end{array}$ & Sesuai \\
\hline
\end{tabular}

Berdasarkan data yang diujikan sistem memperoleh 45 hasil diagnosis yang sama dengan pakar dan 7 hasil diagnosis yang berbeda dan mendapatkan nilai akurasi sebesar 86,53\%. Berikut rumus menghitung nilai akurasi, yang dapat dilihat pada Rumus 2.

Akurasi $=\frac{\text { Jumlah data sesuai }}{\text { Jumlah data uji }} \times 100 \%$

Akurasi $=\frac{45}{52} \times 100 \%=86,53 \%$

\section{KESIMPULAN DAN SARAN}

\section{Kesimpulan}

Kesimpulan dari penelitian Sistem Pakar Untuk Mendiagnosis Hama Dan Penyakit Tanaman Pisang Dengan Teorema Bayes, sebagai berikut:

1. Sistem pakar berbasis website yang telah dibangun dengan menerapkan metode Teorema Bayes berhasil dalam mendiagnosis hama dan penyakit tanaman pisang dengan memberikan informasi terkait hama atau penyakit yang terdeteksi beserta dengan cara mengatasinya.

2. Berdasarkan hasil pada evaluasi sistem dengan membandingkan hasil diagnosis pakar dan sistem menggunakan 52 data uji, adanya perbedaan hasil diagnosis antara pakar dan sistem disebabkan oleh terdapatnya lebih dari satu hama atau penyakit yang dapat menyerang tanaman pisang, serta pakar mendiagnosis hama atau penyakit dengan melihat gejala yang paling tipikal (khas) dari masing-masing hama dan penyakit, karena pada tanaman pisang seringkali timbul gejala

Lievia Anjhelina Maharani, Gibtha Fitri Laxmi, Freza Riana Jurnal Ilmiah Teknologi Informasi Terapan Volume 8, No 1, 15 Desember 2021 
yang tidak spesifik atau seringkali serangan hama dan penyakit menimbulkan gejala yang mirip.

\section{Saran}

Saran penulis pada penelitian selanjutnya ialah perlu adanya penambahan metode yang dapat mendeteksi perilaku pakar dalam mendiagnosis hama atau penyakit tanaman pisang, dan metode yang berhubungan dengan kemunculan gejala, seperti metode fuzzy.

\section{REFERENSI}

Riana, F., \& Primasari, D. (2019). Diagnosis Penyakit Utama Pisang Karena Jamur Patogen dengan Dempster-Shafer. KREA-TIF: JURNAL TEKNIK INFORMATIKA vol 7, no 2, 73-79.

Kusrini. (2006). Sistem Pakar, Teori dan Aplikasi. Yogyakarta: ANDI.

Siregar, E. T. (2015). PENERAPAN TEOREMA BAYES PADA SISTEM PAKAR UNTUK MENGIDENTIFIKASI PENYAKIT TUMBUHAN PADI. Seminar Nasional Informatika 2015, 23-26.

Suhartanto, M. R., Sobir, \& H. H. (2012). Teknologi Sehat Budidaya Pisang. Bogor: Pusat Kajian Hortikultura Tropika, LPPM-IPB.

Hayadi, B. H. (2018). Sistem Pakar Penyelesaian Kasus Menentukan Minat Baca, Kecenderungan, dan Karakter Siswa dengan Metode Forward Chaining. Yogyakarta: Deepublish.

Ramadhan, P. S., \& S.Pane, U. F. (2018). Metode Sistem Pakar. Sidoarjo: Uwais Inspirasi Indonesia. 